\title{
Academic Turkish for international students: Problems and suggestions*
}

\author{
Dursun Demir $^{a} \dagger$ (iD), Ayten Genç ${ }^{b}$ (iD \\ ${ }^{a}$ Tokat Gaziosmanpaşa University, School of Foreign Languages,Tokat, 60100, Turkey \\ ${ }^{b}$ Hacettepe University, Faculty of Education, Ankara, 06800, Turkey
}

APA Citation:

Demir, D. \& Genç, A. (2019). Academic Turkish for international students: Problems and suggestions. Journal of Language and Linguistic Studies, 15(1), 34-47.

Submission Date:11/09/2018

Acceptance Date:03/12/2018

\begin{abstract}
Turkey has hosted many international students from various countries in recent years. After learning Turkish in Turkish language teaching centers of the universities, these students move onto their undergraduate or graduate studies at different departments where they are required to use Turkish in all academic skills without reservation. The aim of this study was to investigate academic Turkish problems of international students. The subjects of the study were 697 international students from 54 universities, and 203 content-area instructors from 15 different universities in Turkey. The quantitative data were gathered through questionnaires and analyzed using Statistical Package for the Social Sciences program and the qualitative data were gathered through semi-structured interviews and analyzed using descriptive analyses. The study revealed that insufficient vocabulary range is the primary source of difficulties international students encounter during the instruction of their content courses. Moreover, instructors are of the opinion that students have much more difficulties in using academic Turkish than they themselves perceive. It is hoped that the results of the present study will contribute to the development of curriculum and materials in such a way as to use it for the benefit of international students pursuing their studies at Turkish universities.
\end{abstract}

(C) 2019 JLLS and the Authors - Published by JLLS.

Keywords: International student; academic language; academic Turkish; language skills; content courses

\section{Introduction}

Academic success of international students depends on how skillfully they use academic language in their studies. The mastery of academic language is regarded as one of the most important factors that distinguish successful students from unsuccessful ones (Wong Fillmore, 2004). Zwiers (2014, p. 22) defines academic language as "the set of words, grammar, and discourse strategies used to describe complex ideas, higher order thinking processes, and abstract concepts." According to him, most people think that academic language consists only of content words, whereas they constitute only one aspect of it. Goldenberg and Coleman (2010, p. 93) agree with Zwiers saying, "Academic language is more than content or technical vocabulary." In literature academic language is generally described being compared with conversational language (see, eg, Cummins 1979; Wong Fillmore 2004; Goldenberg \& Coleman

\footnotetext{
* This study was derived from the doctoral dissertation entitled “Academic Turkish Needs of International Students" Demir, Dursun (2017) at Hacettepe University.

† Corresponding author. Tel.: +90-356-252-1616, ext. 2524

E-mail address: demirdursun@hotmail.com
} 
2010). In this sense, Cummins (1979) was one of the first researches to make that comparison. He used "basic interpersonal communicative skills" (BICS) for conversational language and "cognitive academic language proficiency" (CALP) for academic language. BICS refers to a language which is "less complex and less abstract and is accompanied by helpful extra-linguistic clues, such as pictures, objects, facial expressions, and gestures... CALP refers to a language which is "complex, and abstract, lacking extralinguistic support" (Zwiers, 2014, p. 22).

\subsection{Literature review}

Goldenberg and Coleman (2010) state that students need academic language for two reasons: to learn the content of their courses and to express what they know. All the students, including native speakers, have to perform different tasks using language when they go to university. "The most obvious of these tasks is the ability to understand complex academic discourse, especially academic research articles and books, as well as course lectures" (Biber, 2006, p. 1). Not only international students but also mother tongue speakers are required to learn and use academic language and they also have difficulties in using it. However, as Baily (2007) puts forward, it is more difficult for an international student to learn academic language. Therefore academic language is more often studied in foreign language teaching contexts (Haneda, 2014) and some studies (see, e.g., Christison \& Krahnke 1986; Johns 1981; Kim 2006; Leki 2001; Liu 2001; Ostler 1980; Phakiti \& Li 2011) on academic English have decidedly shown that international students have difficulties in using academic language skills properly. The reason that makes academic language difficult for international students is its having some features different from everyday language. Long and complex sentences, nominalizations, lexical density (especially abstract and low-frequency vocabulary), formality, hedging, impersonality and abundance of passive voice sentences are among the features that make it more difficult to comprehend. Nominalization, for example, "means turning verbs or adjectives into noun phrases that then become the subject or object in a clause or phrase. The purpose of nominalization is to condense what can often amount to lengthy explanations into a few words" (Zwiers, 2014, p. 39). In other words, nominalization allows writers to express a lot of information with a few words, which in turn makes comprehension of those clauses more difficult for readers.

Recently, some studies on academic Turkish have been carried out. These studies can be classified into three groups: Some of them (see, e.g., studies by Akbaş 2012 and 2014; Bayyurt 2010; Çakır \& Kansu Yetkiner 2010 and 2011; Çakır \& Özden 2015; Çandarlı 2012) compared Turkish academic texts with those of English ones in terms of some aspects of language use, some of them (see, e.g., studies by Doyuran 2009; Yıldız \& Aksan 2013; Çalışır Zenci 2009; Türkkan \& Yağcığlu 2006; Uzun \& Huber 2002; Dağ Tarcan 2017) focused on Turkish academic texts, and the rest (see, e.g., studies by Tok 2013; Yahşi Cevher \& Güngör 2015 and 2016; Dolmacı \& Ertaş 2016; Boylu 2016; Haidari \& Yanpar Yelken 2018; Kesten, Kırkoğlu, \& Elma 2010; Gürbüz \& Güleç 2016; Y1lmaz, 2017) were undertaken with or for international students. Tok's (2013) study is one of the first one in this sense. He worked on academic writing needs of international students and found out that students have problems as to how to plan and write texts, form well-structured sentences, and develop coherent paragraphs with appropriate titles using academic style and necessary vocabulary. Yahşi Cevher and Güngör (2015) interviewed 21 international students and found out that students have difficulties in understanding content vocabulary. They have concluded that academic Turkish courses for international students are necessary and content vocabulary in these courses should be taught by content course instructors. Their second study (Yahşi Cevher \& Güngör, 2016) with 18 content course instructors has revealed that students have difficulties in understanding the content courses. Instructors have reported that this difficulty is due to (1) the students' poor academic background they had in their own countries, (2) their limited vocabulary size 
(3) the fact that they do not seem to have developed their academic skills concurrently all the way through their intensive programs.

One of the limitations of the previous studies on international students' academic Turkish usage is that they have been carried out at one or two universities, with 13-85 participants using either qualitative or quantitative methods. However, the present study has been carried out at 54 different universities using two different sources (students and instructors) and two different methods (surveys and interviews) and thus it is a mixed method study and provides a more comprehensive picture of the difficulties international students face in using academic Turkish. Besides, none of the previous studies based their research design on four language skills and sub skills concurrently, which would make it possible to reveal the exact nature of international students' problems. Therefore, this study is an attempt to fill in this gap.

Majority of the international students come to Turkey in order to pursue undergraduate or graduate studies for the degrees in the aftermath of the programs concerned. Students whose Turkish language competency is not enough are required to take pre-academic intensive Turkish courses in Turkish language teaching centers of the universities. After these courses students begin studying their subjects at different departments, which means transferring themselves from general Turkish language learners to academic Turkish users. It is possible that the change of environment paves the way for new problems and a wide variety of needs they are challenged to meet. Lecturers of Turkish as a foreign language should know what is expected of their students at content courses. The task of them is not only to teach Turkish but, as Kim (2006) puts forward, to help students move smoothly from language courses to content-courses as well. In order for students to have no problems regarding the use of academic language skills before they return to their departments, Turkish language instructors should be familiar with the requirements of content courses and the problems students face in these courses.

\subsection{Research questions}

The aim of this study, carried out with the largest sampling research instrument ever in the field of academic Turkish, was to determine international students' problems with the proper use of academic Turkish in their field of study. The present study was developed with the following questions in mind:

1. Considering four basic language skills, which one is the most difficult for international students in academic settings?

1.1. What is the most difficult reading sub-skill for international students in academic settings?

1.2. What is the most difficult writing sub-skill for international students in academic settings?

1.3. What is the most difficult speaking sub-skill for international students in academic settings?

1.4. What is the most difficult listening sub-skill for international students in academic settings?

2. What similarities and differences can be found in the responses of students and those of content course instructors?

\section{Method}

For the study, quantitative data were collected through the students' and instructors' questionnaires and qualitative data were obtained through semi-structured student interviews. In order to carry out this mixed method study, the researchers first conducted a group interview with 20 international students at a Turkish university. The data collected from this interview provided the necessary input for the design of the three instruments used in the study. 


\subsection{Participants}

The participants included 697 international students and 203 content course instructors. Seventy-one percent of the students were undergraduate and twenty-nine percent of them were graduate students. They studied their subjects at 54 different Turkish universities. They were native speakers of 79 different languages. The largest L1 group represented was Arabic (28\%), followed by Turkmen (12\%) and Somali (7\%). The majority of the students aged between 20 and 24 years of age. They were 515 males and 182 females. 43 of the 697 students who answered the questionnaire also participated in semi-structured interviews.

Content course instructors were from 15 different Turkish universities. Sixty-six percent of them taught undergraduate courses and thirty-four percent of them taught graduate courses to international students. The majority of the instructors had more than ten years of experience in higher education. They were 133 males and 70 females.

\subsection{Instruments}

Three instruments were used in this study: (1) students' questionnaire, (2) instructors' questionnaire and (3) students' interviews. Both questionnaires consisted of five parts: demographics, frequency of usage of four skills, the importance of some academic tasks, the difficulty of four skills and that of subskills. However, due to space limitations, only the data gathered from the last two parts of the questionnaires were discussed in this paper. The instructors' questionnaire had the same items with that of students' but wording of some items were different.

For the interviews, a list of questions was prepared. These questions tried to elicit the information on difficulties of students in using academic Turkish. All the three instruments were prepared and administered in Turkish. The drafts of the three instruments were piloted with the participation of 25 students and 3 instructors. After minor changes suggested by the students and instructors, the instruments were finalized for data collection.

\subsection{Data collection and analysis}

In order to collect as much information as possible, two different procedures were followed in administering the student questionnaire. In the first one, the questionnaire link was sent via e-mail by the Presidency for Turks Abroad and Related Communities* to some of its scholarship students and 249 of them completed the questionnaire. The second procedure included one of the researchers' visiting 8 universities to administer the questionnaire. This provided the researchers with 448 completed questionnaires. On the other hand, an e-mail appeal including a link to the questionnaire was sent to the instructors, which resulted in 203 completed questionnaires. Data for the study were collected between June and November 2016.

Semi-structured interviews were conducted by the first researcher with 43 participating students. Each interview took an average of 15 minutes. All the interviews were recorded and then transcribed. Interview data were analyzed by means of descriptive analysis. Quantitative data were statistically analyzed using the Statistical Package for the Social Sciences (SPSS) version 20.0. Statistical procedures employed included descriptive statistics for the questionnaire items (totals, means, and standard deviations) and independent samples t- test to examine the differences between the students' responses and those of the instructors. A five-scale Likert response format was used in the last two parts of the questionnaires where the difficulty of the language skills and that of sub-skills was assessed. In order to

\footnotetext{
$\ddagger$ It is a governmental organisation which gives scholarship to some international students.
} 
calculate the means, each item in the questionnaires was given a value: (1) very easy, (2) easy, (3) neutral, (4) difficult, (5) very difficult. Means were calculated using these values.

The 35 items which aimed at assessing international students' difficulties in language sub-skills were grouped under four headings in the questionnaires: Academic reading, academic writing, academic speaking and academic listening. In order to assess the reliability of the survey instruments Cronbach's coefficient alpha was calculated for each of these four sections and it was found to be 0.90 for academic reading, 0.89 for academic writing, 0.87 for academic speaking and 0.88 for academic listening sections of the students' questionnaire. Cronbach's coefficient alpha values of academic reading, writing and listening sections of instructors' questionnaire was found to be 0.90 and that of academic speaking section was found to be 0.88 . According to Alpar (2010), these values showed that the two instruments were highly reliable.

\section{Results}

\subsection{Students' difficulties with four language skills}

The first research question asked about participants' perceptions on the difficulty using four language skills. Table 1 presents findings related to this question.

Table 1. Comparison of students' and instructors' responses on difficulty level of four language skills

\begin{tabular}{|c|c|c|c|c|c|c|}
\hline Skills & Participants & $\mathbf{N}$ & Mean & SD & $t$ & $p$ \\
\hline \multirow{2}{*}{ Reading } & Students & 697 & 2.74 & 1.07 & \multirow{2}{*}{-8.54} & \multirow{2}{*}{.000} \\
\hline & Instructors & 203 & 3.33 & 0.79 & & \\
\hline \multirow{2}{*}{ Writing } & Students & 697 & 2.83 & 1.10 & \multirow{2}{*}{-14.38} & \multirow{2}{*}{.000} \\
\hline & Instructors & 203 & 3.89 & 0.86 & & \\
\hline \multirow{2}{*}{ Speaking } & Students & 697 & 2.57 & 1.13 & \multirow{2}{*}{-8.99} & \multirow{2}{*}{.000} \\
\hline & Instructors & 203 & 3.19 & 0.78 & & \\
\hline \multirow{2}{*}{ Listening } & Students & 697 & 2.61 & 1.19 & \multirow{2}{*}{-9.40} & \multirow{2}{*}{.000} \\
\hline & Instructors & 203 & 3.31 & 0.84 & & \\
\hline
\end{tabular}

The results showed agreement between the two groups on the rank of skills according to difficulty. Both students and instructors consider writing the most difficult skill, followed by reading, listening and speaking respectively. These results indicate that students have the most difficulty with writing. On the other hand, it should be noted that the difference between students and instructors means on four language skills is statistically significant according to independent samples $t$ test $(\mathrm{p}<.05)$. These results show that according to instructors, students have much more difficulties in four language skills than they themselves can perceive.

\subsection{Students' difficulties with sub-skills}

The following tables show the comparison of the students' and instructors' responses to the items related to sub-skills in the questionnaire. 
Table 2. Comparison of students' and instructors' responses on difficulty level of reading sub-skills

\begin{tabular}{|c|c|c|c|c|c|c|}
\hline Academic Reading & Participants & $\mathbf{N}$ & Mean & SD & $t$ & $p$ \\
\hline \multirow{2}{*}{1 Identifying the main idea } & Students & 697 & 2.83 & 1.01 & \multirow[b]{2}{*}{-8.44} & \multirow[b]{2}{*}{.000} \\
\hline & Instructors & 203 & 3.40 & 0.79 & & \\
\hline \multirow{2}{*}{$\begin{array}{l}2 \text { Answering the comprehension } \\
\text { questions about a text }\end{array}$} & Students & 697 & 2.88 & 0.91 & \multirow[b]{2}{*}{-8.50} & \multirow[b]{2}{*}{.000} \\
\hline & Instructors & 203 & 3.39 & 0.70 & & \\
\hline \multirow{2}{*}{3 Skimming } & Students & 697 & 2.83 & 0.98 & \multirow[b]{2}{*}{-5.73} & \multirow[b]{2}{*}{.000} \\
\hline & Instructors & 203 & 3.20 & 0.75 & & \\
\hline \multirow{2}{*}{4 Summarizing } & Students & 697 & 2.95 & 0.97 & \multirow[b]{2}{*}{-7.52} & \multirow[b]{2}{*}{.000} \\
\hline & Instructors & 203 & 3.44 & 0.78 & & \\
\hline \multirow{2}{*}{5 Guessing the meaning of new words } & Students & 697 & 2.95 & 0.96 & \multirow[b]{2}{*}{-9.52} & \multirow[b]{2}{*}{.000} \\
\hline & Instructors & 203 & 3.57 & 0.77 & & \\
\hline \multirow{2}{*}{6 Making inferences } & Students & 697 & 2.87 & 0.92 & \multirow[b]{2}{*}{-7.86} & \multirow[b]{2}{*}{.000} \\
\hline & Instructors & 203 & 3.37 & 0.77 & & \\
\hline \multirow{2}{*}{7 Expressing your ideas about a text } & Students & 697 & 2.83 & 0.97 & \multirow[b]{2}{*}{-10.68} & \multirow{2}{*}{.000} \\
\hline & Instructors & 203 & 3.55 & 0.81 & & \\
\hline \multirow{2}{*}{8 Reading quickly } & Students & 697 & 2.85 & 1.10 & \multirow[b]{2}{*}{-13.81} & \multirow[b]{2}{*}{.000} \\
\hline & Instructors & 203 & 3.89 & 0.90 & & \\
\hline \multirow{2}{*}{$\begin{array}{l}9 \text { Understanding specialist vocabulary } \\
\text { related to the subject matter }\end{array}$} & Students & 697 & 2.98 & 0.95 & \multirow[b]{2}{*}{-7.85} & \multirow[b]{2}{*}{.000} \\
\hline & Instructors & 203 & 3.52 & 0.84 & & \\
\hline \multirow{2}{*}{10 Scanning } & Students & 697 & 2.94 & 1.00 & \multirow[b]{2}{*}{-10.13} & \multirow[b]{2}{*}{.000} \\
\hline & Instructors & 203 & 3.66 & 0.85 & & \\
\hline
\end{tabular}

Students report that they are most concerned about understanding specialist vocabulary and guessing the meaning of unknown words while instructors consider reading quickly to be students' most difficult sub-skill, followed by scanning. According to students, vocabulary related sub-skills cause the greatest trouble in reading but instructors are of the opinion that students experience greater difficulty with reading quickly. The quantitative data seems to merge the perceptions of the students and those of instructors. Three common issues related to academic reading difficulty observed in the qualitative data were as follows: vocabulary, reading speed and grammar. $88 \%$ of the participants stated that they have great difficulties understanding new vocabulary, especially technical ones. Reading slowly was reported to be a problem by $53 \%$ of the students. Some students expressed their views regarding these three problems:

Sentences are full of specialist vocabulary (Student 26) $)^{\text {. }}$

I read slowly. If my native speaker friend reads a page in 5 minutes, I can read it in 15 minutes (Student 18).

I have difficulties in comprehending what I read. Because the textbooks are full of passive and causative sentences. They are written in academic language. But the books at pre-academic intensive courses were simplified (Student 31).

\footnotetext{
$\S$ In order to keep the names of the students confidential, some codes (Student 1, Student 2) were given to them.
} 
Table 3. Comparison of students' and instructors' responses on difficulty level of writing sub-skills

\begin{tabular}{|c|c|c|c|c|c|c|}
\hline Academic Writing & Participants & $\mathbf{N}$ & Mean & SD & $t$ & $p$ \\
\hline \multirow{2}{*}{$\begin{array}{l}11 \text { Making sentences using appropriate } \\
\text { vocabulary }\end{array}$} & Students & 697 & 2.88 & 1.02 & \multirow[b]{2}{*}{-12.45} & \multirow[b]{2}{*}{.000} \\
\hline & Instructors & 203 & 3.74 & 0.82 & & \\
\hline \multirow{2}{*}{12 Linking sentences smoothly } & Students & 697 & 2.80 & 0.99 & \multirow[b]{2}{*}{-14.08} & \multirow{2}{*}{.000} \\
\hline & Instructors & 203 & 3.74 & 0.79 & & \\
\hline \multirow{2}{*}{13 Writing coherent paragraphs } & Students & 697 & 2.89 & 0.99 & \multirow[b]{2}{*}{-13.67} & \multirow[b]{2}{*}{.000} \\
\hline & Instructors & 203 & 3.80 & 0.78 & & \\
\hline \multirow{2}{*}{14 Expressing ideas in correct Turkish } & Students & 697 & 2.82 & 1.00 & \multirow[b]{2}{*}{-16.05} & \multirow[b]{2}{*}{.000} \\
\hline & Instructors & 203 & 3.98 & 0.87 & & \\
\hline \multirow{2}{*}{15 Using specialist vocabulary correctly } & Students & 697 & 2.94 & 0.92 & \multirow[b]{2}{*}{-10.33} & \multirow{2}{*}{.000} \\
\hline & Instructors & 203 & 3.65 & 0.83 & & \\
\hline \multirow{2}{*}{16 Using appropriate academic style } & Students & 697 & 3.17 & 0.99 & \multirow[b]{2}{*}{-9.23} & \multirow[b]{2}{*}{.000} \\
\hline & Instructors & 203 & 3.88 & 0.96 & & \\
\hline \multirow{2}{*}{17 Spelling and punctuation } & Students & 697 & 2.85 & 1.01 & \multirow[b]{2}{*}{-13.83} & \multirow[b]{2}{*}{.000} \\
\hline & Instructors & 203 & 3.87 & 0.90 & & \\
\hline \multirow{2}{*}{18 Revising written work } & Students & 697 & 2.78 & 0.95 & \multirow[b]{2}{*}{-10.99} & \multirow[b]{2}{*}{.000} \\
\hline & Instructors & 203 & 3.52 & 0.80 & & \\
\hline
\end{tabular}

In academic writing, students state that their biggest difficulty is in using appropriate academic style. They have reported that using specialist vocabulary correctly is their second most difficult writing subskill. On the other hand, according to instructors students seem to have the highest difficulty in expressing ideas in correct Turkish, followed by using appropriate academic style. The analysis of the interview data indicates that students generally find it difficult to write grammatically correct sentences and use appropriate academic style. The findings suggest that students experience great difficulties in using appropriate academic style, expressing ideas in correct Turkish and using specialist vocabulary correctly. The analysis of the interview data indicates that students generally find it difficult to write grammatically correct sentences and use appropriate academic style:

I have difficulties in finding the correct suffixes to combine the words to each other (Student 6).

I can't write grammatically correct sentences (Student 11).

We have some difficulties when writing in academic language. Writing during the pre-academic intensive courses was easier, but now it is difficult to write academic papers, as it is more challenging (Student 30).

Table 4. Comparison of students' and instructors' responses on difficulty level of speaking sub-skills

\begin{tabular}{|c|c|c|c|c|c|c|}
\hline Academic Speaking & Participants & $\mathbf{N}$ & Mean & SD & $t$ & $p$ \\
\hline \multirow{2}{*}{19 Speaking accurately } & Students & 697 & 2.77 & 1.02 & \multirow{2}{*}{-7.91} & \multirow[b]{2}{*}{.000} \\
\hline & Instructors & 203 & 3.29 & 0.74 & & \\
\hline \multirow{2}{*}{20 Speaking fluently } & Students & 697 & 2.94 & 1.10 & \multirow{2}{*}{-10.11} & \multirow{2}{*}{.000} \\
\hline & Instructors & 203 & 3.67 & 0.84 & & \\
\hline \multirow{2}{*}{21 Asking and answering questions } & Students & 697 & 2.66 & 0.97 & \multirow{2}{*}{-10.67} & \multirow{2}{*}{.000} \\
\hline & Instructors & 203 & 3.36 & 0.77 & & \\
\hline \multirow{2}{*}{22 Choosing right words when speaking } & Students & 697 & 2.77 & 0.96 & \multirow{2}{*}{-10.35} & \multirow[b]{2}{*}{.000} \\
\hline & Instructors & 203 & 3.43 & 0.71 & & \\
\hline
\end{tabular}




\begin{tabular}{|c|c|c|c|c|c|c|}
\hline \multirow{2}{*}{$\begin{array}{l}23 \text { Speaking without making } \\
\text { pronunciation mistakes }\end{array}$} & Students & 697 & 2.99 & 1.08 & \multirow[b]{2}{*}{-11.70} & \multirow[b]{2}{*}{.000} \\
\hline & Instructors & 203 & 3.86 & 0.88 & & \\
\hline \multirow{2}{*}{24 Participating in discussions } & Students & 697 & 2.92 & 0.97 & \multirow{2}{*}{-11.32} & \multirow{2}{*}{.000} \\
\hline & Instructors & 203 & 3.73 & 0.87 & & \\
\hline \multirow{2}{*}{$\begin{array}{l}25 \text { Using visual aids (pictures, charts, } \\
\text { etc.) while speaking }\end{array}$} & Students & 697 & 2.78 & 0.96 & \multirow{2}{*}{-3.69} & \multirow[b]{2}{*}{.000} \\
\hline & Instructors & 203 & 3.12 & 0.84 & & \\
\hline \multirow{2}{*}{26 Using stress and intonation correctly } & Students & 697 & 2.88 & 1.00 & \multirow{2}{*}{-10.56} & \multirow{2}{*}{.000} \\
\hline & Instructors & 203 & 3.64 & 0.86 & & \\
\hline
\end{tabular}

Students and instructors share the view that international students have great difficulty in speaking without making pronunciation mistakes. Students have reported speaking fluently as their second most difficult skill while instructors have reported it to be participating in discussions (see Table 4). Interviews with students revealed that some of them have difficulties in speaking due to shyness. In this sense, some of their answers included phrases like "I'm afraid to make mistakes, I feel embarrassed, I may be misunderstood, I am shy with my friends, I am nervous". As one student said:

I hesitate to ask a question in class. Then I decide not to ask and find the answer at home. But when I get home, I say "I wish I had asked it in class", because I can 't do anything at home (Student 2).

Many students who are hesitant to speak in the classroom or who prefer not to speak for different reasons report that they are more comfortable speaking outside the classroom:

I feel free to speak in the street, but not with the instructor. Mistakes are not that important in the street but when talking to the instructors you should pay attention to your words. That's why it is difficult (Student 42).

Table 5. Comparison of students' and instructors' responses on difficulty level of listening sub-skills

\begin{tabular}{|c|c|c|c|c|c|c|}
\hline Academic Listening & Participants & $\mathbf{N}$ & Mean & SD & $t$ & $p$ \\
\hline \multirow{2}{*}{27 Identifying the topic of a lecture } & Students & 697 & 2.40 & 0.91 & \multirow[b]{2}{*}{-9.74} & \multirow[b]{2}{*}{.000} \\
\hline & Instructors & 203 & 3.06 & 0.84 & & \\
\hline \multirow{2}{*}{28 Identifying the main idea of a lecture } & Students & 697 & 2.71 & 0.98 & \multirow[b]{2}{*}{-6.54} & \multirow[b]{2}{*}{.000} \\
\hline & Instructors & 203 & 3.19 & 0.90 & & \\
\hline \multirow{2}{*}{29 Guessing the meaning of new words } & Students & 697 & 2.87 & 0.99 & \multirow[b]{2}{*}{-10.90} & \multirow[b]{2}{*}{.000} \\
\hline & Instructors & 203 & 3.57 & 0.74 & & \\
\hline \multirow{2}{*}{$\begin{array}{l}30 \text { Understanding non-standard/regional } \\
\text { accents }\end{array}$} & Students & 697 & 2.95 & 0.97 & \multirow[b]{2}{*}{-17.01} & \multirow[b]{2}{*}{.000} \\
\hline & Instructors & 203 & 4.24 & 0.84 & & \\
\hline \multirow{2}{*}{31 Taking notes } & Students & 697 & 2.81 & 1.01 & \multirow[b]{2}{*}{-11.38} & \multirow[b]{2}{*}{.000} \\
\hline & Instructors & 203 & 3.58 & 0.79 & & \\
\hline \multirow{2}{*}{32 Following a discussion } & Students & 697 & 2.76 & 0.94 & \multirow[b]{2}{*}{-10.21} & \multirow[b]{2}{*}{.000} \\
\hline & Instructors & 203 & 3.42 & 0.76 & & \\
\hline \multirow{2}{*}{33 Understanding questions } & Students & 697 & 2.66 & 0.94 & \multirow[b]{2}{*}{-6.97} & \multirow[b]{2}{*}{.000} \\
\hline & Instructors & 203 & 3.26 & 0.74 & & \\
\hline \multirow{2}{*}{34 Understanding key vocabulary } & Students & 697 & 2.72 & 0.93 & \multirow[b]{2}{*}{-10.16} & \multirow[b]{2}{*}{.000} \\
\hline & Instructors & 203 & 3.41 & 0.82 & & \\
\hline \multirow{2}{*}{$\begin{array}{l}35 \text { Understanding instructors' spoken } \\
\text { directions regarding assignments }\end{array}$} & Students & 697 & 2.71 & 0.96 & \multirow[b]{2}{*}{-7.38} & \multirow[b]{2}{*}{.000} \\
\hline & Instructors & 203 & 3.18 & 0.73 & & \\
\hline
\end{tabular}


The findings related to academic listening suggest that understanding non-standard accents causes the greatest trouble. According to students guessing the meaning of new words is their second most difficult listening skill, whereas according to instructors it is taking notes. According to qualitative data, key problems associated with their academic listening difficulties were unknown words, the speed of instructors' spoken Turkish and taking notes during their lectures:

Understanding what the instructor says is sometimes difficult for me. When he talks about a topic, my Turkish friends can understand him easily but I can't...Words... I don't have a wide vocabulary range. Some words... I know them in Arabic and English but I don't know them in Turkish (Student 25).

Some instructors speak very fast. It's difficult to understand them (Student 31).

I can't take notes. As I said before, if I take notes, I can't keep up with the teachers. They speak fast. They don't speak slowly considering we are foreigners (Student 37).

You will ether listen to the teacher or take notes. If you take notes, you can't keep up with the teacher (Student 41).

Moreover, some students reported that when listening to lectures they take notes in their mother tongues or in English due to the difficulty of taking notes in Turkish.

\section{Discussion}

By using two different sources and methods the present study investigated the problems international students encounter in using academic Turkish and gathered the necessary data for curriculum and materials development. Answers to the research questions have revealed that international students in Turkey have the greatest difficulty in writing. This finding is consistent with those of Haidari and Yanpar Yelken (2018), Hyland (1997) and Burke and Claire (1996). Writing was followed by reading, listening and speaking respectively. Analysis of the qualitative data has shown that writing is also the least used skill. The fact that writing is the least used but most challenging skill may indicate that there is an inverse proportion between skills' usage frequency and their difficulty levels because the frequency of writing assignments and their regular checks by the instructors for correction help improve academic writing skill to the extent that students will have little or no difficulty in the actual use of the target language. This is due to the fact that students will be able to find ample opportunity to improve their skills on a regular basis by moving from controlled to semi-controlled and finally to free writing exercises in the process of time. Moreover, that students are mostly evaluated through written examinations in Turkey may be another factor that makes writing difficult for themselves, since they do not spent as much time as necessary for the acquisition of proper academic writing skill to be in place. According to the results of the students' questionnaire, students have the biggest difficulty in using appropriate academic style in terms of writing sub-skills, which coincides with the findings of Evans and Green (2007).

It was found in the current study that students also have difficulties in academic reading and this difficulty is mostly caused by the new and content-specific words in their textbooks. This finding is consistent with those of Yahşi Cevher and Güngör (2015), Evans and Green (2007), and Phakiti and Li (2011).

Among speaking sub-skills, the finding that students were most concerned about speaking without making pronunciation mistakes contradicted Evans and Green's (2007) findings. They found that speaking accurately was the biggest concern for their students and pronunciation was their third most difficult skill. This contradiction may result from the different demographic profiles of the two studies. While the present study surveyed international students, the students in Evans and Green's study studied at an English-medium university in their home countries and most probably spoke their mother tongues 
outside the university. One of the results of this study in terms of academic listening is that understanding non-standard accents is the biggest concern for international students.

The analysis of 35 sub-skills in both questionnaires demonstrates that vocabulary-related ones are among the first two most difficult sub-skills in academic reading, academic writing, and academic listening. Interviews with students revealed that in reading and listening due to unknown vocabulary they experience great difficulties in understanding lectures. These findings suggest that insufficient vocabulary range is the primary source of difficulties they encounter during the instruction of their content courses. This result is consistent with the view of Saville-Troike (1984, p. 199), who foregrounds the fact that "vocabulary knowledge is the single most important area of second language competence."

Although the speaking and listening sub-skills that students have the greatest difficulty in are the same according to two groups of participants, the groups disagree on the most difficult reading and writing sub-skills. The biggest problem of students in academic reading is insufficient vocabulary range according to themselves but according to instructors it is reading slowly. In fact, these two sub-skills are interrelated, because unknown words reduce the text-reading speed. Therefore, while students seem to have expressed the cause of the problem instructors seem to have expressed the result of that problem. In academic writing, students report that their biggest concern is using appropriate academic style but the instructors claim that it is expressing ideas in correct Turkish because students make grammatical mistakes when writing. According to instructors this problem is more important than using academic style and therefore students, first of all, need to learn how to express their ideas in correct Turkish.

The responses of the students about the ranking of the four skills in terms of difficulty overlap completely with those of instructors. Both groups report that students have the highest difficulty with writing and the least difficulty with speaking. On the other hand, when the mean scores of the two groups are compared, a statistically significant difference emerges. Students perceive themselves as being more successful and having less difficulty in using four skills and sub-skills, whereas instructors are of the opinion that students experience much more difficulties than they themselves discern. Another possible explanation could be that students fail to live up to instructors' expectations regarding academic Turkish usage.

\section{Conclusions}

The number of international students increases each year in Turkey. The identification of the skills and sub-skills with which these students have difficulties indicates that the language learning-related issues are to be handled urgently with due care and effort. First of all, in order to design and develop pre-academic intensive Turkish courses and academic Turkish courses, it seems necessary to constitute a committee where program designers, lecturers of Turkish as a foreign language, content course instructors and experts of Turkish language cooperate and collaborate as best they can. Besides designing courses, this committee should also be included in course book writing process. The results of the studies carried out on both teaching Turkish as a foreign language and academic Turkish should be taken into account by this committee. Just as the number of international students increases, the countries these students come from diversify each year, and therefore teaching materials should also be developed and updated according to the needs of changing student profile.

This study has shown that academic Turkish courses are necessary. Students starting undergraduate or graduate studies after pre-academic intensive Turkish courses encounter academic Turkish at their departments. Considering the language difficulties these students have, they should be offered academic Turkish courses. The focus of these courses should be on reading and writing skills where subjectspecific vocabulary instruction is emphasized. In order to do this, academic Turkish courses should be 
organized with a content-based approach. In such courses students will be able to both improve their Turkish language skills and increase their field knowledge leading them to be more willing and motivated in their efforts to learn Turkish as a foreign language for either specific or purely academic purposes.

One of the most important results of the study regarding sub-skills is students' insufficient vocabulary range. Hence, special attention should be given to teaching academic and content-specific words that they find difficulty in the use of all their academic skills during their training in academic Turkish courses. Teaching 1010 words in the Academic Turkish Wordlist prepared by Dolmac1 and Ertaş (2016) will be beneficial in terms of increasing success of international students. Another useful application in this sense, as Hellekjaer (2010) states, is the explanation of key words by the instructors before lectures.

Students need help to improve their note taking skills. They should be taught how to take effective notes in pre-academic intensive courses and academic Turkish courses. The analysis of qualitative data revealed that students care about taking notes when listening to the instructors but they also have great difficulties in this skill; therefore, although lectures are given in Turkish, some students take notes in their mother tongues or in English.

The role of the students as language learners in pre-academic intensive courses changes when they go to their departments. In this new medium, they are supposed to be competent language users with all the skills acquired beforehand and the language they are expected to use should be accurate academic Turkish. Moreover, contrary to the language teachers who speak according to the level of their students, at the departments there are content course instructors, most of whom do not simplify their speech in order for international students to understand what they teach at the time. Language teachers should be aware of these difficulties and the expectations of the departments. The best way to do this is to observe their students during their content courses. Students, too, can take responsibilities in this sense and when they are at B2 level while taking intensive courses, they can join some of the content courses at their prospective departments as guest students. This will allow them to be familiar with the difficulties they are possible to encounter beforehand, and thus they can make the necessary preparations to overcome these difficulties.

This study was carried out to identify the problems international students face in using academic Turkish. Several important issues and pedagogical implications for academic Turkish course planning and material development have also emerged during the present study. The next step is to evaluate these issues, consider implications made by ad-hoc committees and carry out necessary follow-up studies to overcome current problems accordingly.

\section{References}

Akbaş, E. (2014). Are they discussing in the same way? Interactional metadiscourse in Turkish writers' texts. In A. Lyda \& K. Warchal (Eds.), Occupying niches: Interculturality, crossculturality and aculturality in academic research (pp. 119-133). London: Springer.

Akbaş, E. (2012). Exploring metadiscourse in master's dissertation abstracts: cultural and linguistic variations across postgraduate writers. International Journal of Applied Linguistics and English Literature, 1(1), 12-26.

Alpar, R. (2010). Spor, sağllk ve eğitim bilimlerinden örneklerle uygulamalt istatistik ve geçerlikgüvenirlik. Ankara: Detay yayınc1lı. 
Bailey, A. L. (2007). Introduction: Teaching and assessing students learning English in school. In A. L. Bailey (Ed.), The language demands of school: Putting academic English to the test (pp. 1-26). New Haven, CT: Yale University Press.

Bayyurt, Y. (2010). Author positioning in academic writing. In S. Zyngier \& V. Viana (Eds.), Avaliaçoes e perspectivas: Mapeando os estudos empiricos na area de humanas (Appraisals and perspectives: Mapping empirical studies in the humanities) (pp 163-184). Rio de Janeiro: The Federal University of Rio de Janeiro.

Biber, D. (2006). University language: A corpus-based study of spoken and written registers. Philadelphia: John Benjamin Publishing Company.

Boylu, E. (2016). Türkçenin yabancı dil olarak öğretiminde akademik Türkçe sorunu. 9. Uluslararası Türkçenin eğitimi-öğretimi kurultayı. Mehmet Akif Ersoy University.

Burke, E., \& Claire, W. S. (1996). Academic and non-academic difficulties: Perceptions of graduate non-English speaking background students. TESL-EJ, 2(1). Retrieved on May 15, 2017 from: http://tesl-ej.org/ej05/a1.html

Christison, M. A., \& Krahnke, K. J. (1986). Student perceptions of academic language study. TESOL Quarterly, 20(1), 61-81.

Cummins, J. (1979). Cognitive/academic language proficiency, linguistic interdependence, the optimum age question, and some other matters. Working Papers on Bilingualism, 19(1), 121-129.

Çakır, H. \& Kansu Yetkiner, N. (2011). Grammatical metaphor and translation: A contrastive study of Turkish and English scientific discourse. In E. D. Adanur (Ed.), IDEA: Studies in English (pp. 497518). New castle upon Tyne: Cambridge Scholars Publishing

Çakır, H. \& Kansu Yetkiner, N. (2010). Nominalization in scientific language: A comparison between Turkish and English. 15. Uluslararası Türk dilbilim kurultayı

Çakır, H. \& Özden, F. (2015). A contrastive study of the rhetorical structure of Turkish and English research article abstracts. In D. Zeyrek, Ç.Sağın Şimşek, U. Ataş \& J. Rehbein (Eds.), Ankara Papers in Turkish and Turkic Linguistics (pp. 367-378). Wiesbaden: Harrossowitz Verlag.

Çalışır Zenci, S. (2009). Türkçe bilimsel metinlerde olumsuzluğun işlevleri. In S. Ay, Ö. Aydın, İ. Ergenç, S. İşsever \& D. Peçenek (Eds.), Essays on Turkish linguistics: Proceedings of the 14th international conference on Turkish linguistics (pp. 247-256). Wiesbaden: Harrossowitz Verlag.

Çandarl1, D. (2012). A cross-cultural investigation of English and Turkish research article abstracts in educational sciences. Studies About Languages, 20(2), 12-16.

Dağ Tarcan, Ö. (2017). Türkçe bilimsel metinlerde etkileşimli üstsöylem belirleyicileri. Ankara Üniversitesi Sosyal Bilimler Dergisi, 8(2), 179-194.

Dolmac1, M., \& Ertaş, A. (2016). Developing a textbook-based academic Turkish wordlist. Procedia Social and Behavioral Sciences, 232, 821-827.

Doyuran, Z. (2009). Conciliation of knowledge through hedging in Turkish scientific articles. Edebiyat Fakültesi Dergisi, 26(1), 85-99.

Evans, S., \& Green, C. (2007). Why EAP is necessary: A survey of Hong Kong tertiary students. Journal of English for Academic Purposes, 6, 3-17.

Goldenberg, C., \& Coleman, R. (2010). Promoting academic achievement among English learners: A guide to the research. Thousand Oaks, CA: Corwin Press. 
Gürbüz, R. and Güleç, İ. (2016). Türkiye' de eğitim gören yabancı öğrencilerin Türkçeye ilişkin görüşleri: Sakarya üniversitesi örneği. Sakarya University Journal of Education, 6(2), 141-153.

Haidari, S. M. \& Yanpar Yelken, T. (2018). Language difficulties that international postgraduate students experience during their education with the medium of Turkish language. Journal of Language and Linguistic Studies, 14(1), 194-210.

Haneda, M. (2014). Introduction: Why should we care about academic language? Linguistics and Education, 26, 88-91.

Hellekjaer, G. O. (2010). Language matters: Assessing lecture comprehension in Norwegian English-medium higher education. In C. Dalton-Puffer, T. Nikula \& U. Smit (Eds.), Language use and language learning in CLIL classrooms (pp. 233-258). Amsterdam: John Benjamins.

Hyland, K. (1997). Is EAP Necessary? A survey of Hong Kong undergraduates. Asian Journal of English Language teaching, 7, 77-99.

Johns, A. M. (1981). Necessary English: A faculty survey. TESOL Quarterly, 15, 51-57.

Kesten, A., Kırkoğlu, K. \& Elma, C. (2010). Language and education problems of international students in Turkey. Sosyal Bilimler Dergisi, 24, 65-84.

Kim, S. (2006). Academic oral communication needs of East Asian international graduate students in non-science and non-engineering fields. English for Specific Purposes, 25, 479-489.

Leki, I. (2001). A narrow thinking system: Nonnative-English-speaking students in group projects across the curriculum. TESOL Quarterly, 35, 39-67.

Liu, J. (2001). Asian students' classroom communication patterns in U.S. universities: An emic perspective. Westport, CT: Ablex.

Ostler, S. E. (1980). A survey of academic needs for advanced ESL. TESOL Quarterly. 14(4), 489502.

Phakiti, A., \& Li, L. (2011). General academic difficulties and reading and writing difficulties among Asian ESL postgraduate students in TESOL at an Australian university. RELC Journal, 42(3), 227264.

Saville-Troike, M. (1984). What really matters in second language learning for academic achievement? TESOL Quarterly, 17, 199-219.

Tok, M. (2013). Türkçenin yabancı dil olarak öğretiminde akademik yazma ihtiyacı. Mustafa Kemal Üniversitesi Sosyal Bilimler Enstitüsü Dergisi, 23, 1-25.

Türkkan, B., \& Yağcıoğlu, S. (2006). Türkçe bilimsel metinlerde gönderimsel bağdaşıklık ve köprü gönderimi: Merkezleme kuramı çerçevesinde bir yaklaşım. Dilbilim Araştırmaları Dergisi, 59-70.

Uzun, L., \& Huber, E. (Eds.). (2002) Türkçede bilgi yapısı ve bilimsel metinler. Essen, Almanya: Die Blaue Eule.

Wong Fillmore, L. (2004). The role of language in academic development. Santa Rosa: CA: Sonoma County Office of Education. Retrieved on November 30, 2015 from:

https://www.scoe.org/docs/ah/AHlanguage.pdf 
Yahşi Cevher, Ö., \& Güngör, C. (2015). Yabanc1 dil olarak Türkçe öğretiminde akademik Türkçenin önemine ilişkin uygulamalı bir araştırma: Türk dili öğretimi uygulama ve araştırma merkezi örneği. International Journal of Languages' Education and Teaching, 2267-2274.

Yahşi Cevher, Ö., \& Güngör, C. (2016). The importance of teaching academic Turkish as a foreign language. The Anthropologist, 24(1), 309-318.

Yıldız, G., \& Aksan, M. (2013). Türkçe bilimsel metinlerde eylemler: Derlem temelli bir inceleme. 27. Ulusal dilbilim kurultayı, 2-4 Mayıs 2013, Antalya, Kemer.

Y1lmaz, İ. (2017). Opinions of Turkish as a foreign language learners on academic Turkish. Advances in Language and Literary Studies, 8(2), 180-189.

Zwiers, J. (2014). Building academic language: Meeting common core standards across disciplines, grades 5-12. San Francisco: CA: Jossey-Bass.

\section{Uluslararası öğrenciler için akademik Türkçe: Sorunlar ve öneriler}

\section{$\ddot{O} \mathbf{z}$}

Türkiye, son yıllarda birçok farklı ülkeden uluslararası öğrenciye ev sahipliği yapmaktadır. Bu öğrenciler, öncelikle üniversitelerin Türkçe Öğretim Merkezlerinde Türkçe öğrenmekte ve daha sonra lisans veya lisansüstü öğrenim görecekleri ve akademik Türkçe kullanmaları gereken bölümlere geçmektedir. Bu çalışmanın amacı, uluslararası öğrencilerin akademik Türkçe sorunlarının araştırılmasıdır. Çalışmanın katılımcıları Türkiye'deki 54 farklı üniversitede öğrenim gören 697 uluslararası öğrenci ile 15 farklı üniversitedeki 203 öğretim elemanından oluşmuştur. Nicel veriler anketler yoluyla elde edilerek Sosyal Bilimler İstatistik Programı ile değerlendirilmiş, nitel veriler ise yarı yapılandırılmış görüşmeler yoluyla elde edilerek betimsel analiz teknikleri kullanılarak analiz edilmiştir. Çalışma sonucunda, uluslararası öğrencilerin bölüm derslerinde karşılaştıkları sorunların temelinde yetersiz kelime bilgilerinin olduğu görülmüsstür. Ayrıca, öğretim elemanları akademik Türkçe kullanırken, uluslararası öğrencilerin kendi beyanlarından daha fazla güçlük çektiğini ifade etmektedir. $\mathrm{Bu}$ araştırma sonuçlarının Türkiye'de öğrenim gören uluslararası öğrencilere yönelik öğretim programları ve malzemelerinin geliştirilmesine katkı sağlayacağı düşünülmektedir.

Anahtar sözcükler: uluslararası öğrenci; akademik dil; akademik Türkçe; dil becerileri; bölüm dersleri

\section{AUTHOR BIODATA}

Dursun Demir is currently working as an instructor at the School of Foreign Languages at Tokat Gaziosmanpaşa University. He holds a PhD in Teaching Turkish as a Foreign Language from Hacettepe University.

Ayten Genç is a professor at Hacettepe University, Faculty of Education, Department of Foreign Language Education. Her research interests include course book analysis, material and curriculum development in teaching German and Turkish as foreign languages. 